Tropical Journal of Pharmaceutical Research October 2016; 15 (10): 2093-2097

ISSN: $1596-5996$ (print); 1596-9827 (electronic)

(C) Pharmacotherapy Group, Faculty of Pharmacy, University of Benin, Benin City, 300001 Nigeria.

All rights reserved.

Available online at http://www.tjpr.org

Original Research Article

http://dx.doi.org/10.4314/tjpr.v15i10.6

\title{
Effect of Turkish propolis extracts on expression of voltage-gated sodium channel Nav 1.5 and 1.7 a-lsoforms in PC-3 human prostate cancer cells
}

\author{
Meltem Uçar ${ }^{1 *}$, Orhan Değer ${ }^{2}$, Yaşam Barlak ${ }^{3}$ \\ ${ }^{1}$ Faculty of Health Sciences, European University of Lefke, 99728, Lefke, Turkish Republic of Northern Cyprus, ${ }^{2}$ Department of \\ Medical Biochemistry, Faculty of Medicine, Karadeniz Technical University, 61080, Trabzon, ${ }^{3}$ Karadeniz Advanced Technology \\ Research and Application Centre (KITAM), Ondokuz Mayıs University, 55210, Samsun, Turkey
}

*For correspondence: Email: mucar@eul.edu.tr; Tel: +90 392660 2000-2554; Fax: +90 3926602553

Received: 11 May 2016

Revised accepted: 10 September 2016

\begin{abstract}
Purpose: To investigate the effect of dimethyl sulfoxide (DMSO) and water extracts of Turkish propolis (WEP) on mRNA expression of Nav 1.5 and $1.7 \alpha$ isoforms of Voltage-Gated Sodium Channel (VGSC) proteins in $P C-3$ human prostate cancer cells.

Methods: DMSO and WEP (20 $\mu \mathrm{g} / \mathrm{mL}$ each) were incubated for $24 \mathrm{~h}$ with PC-3 cells and total RNA was extracted using a commercial kit. Real-time polymerase chain reaction (RTPCR) assay was used to determine mRNA levels of the isoforms of VGSC. Expressions of VGSC were assumed to be $100 \%$ in $P C-3$ cells incubated without extract.

Results: Both extracts decreased the expression of VGSC isoforms to varying extents. Expressions of Nav 1.5 and 1.7 was $61.43 \pm 4.92$ and $58.17 \pm 2.88 \%$, respectively for DMSO; while for WEP, the values were $83.54 \pm 15.96$ and $80.40 \pm 13.8720 \mu \mathrm{g} / \mathrm{mL}$, respectively.

Conclusion: This results suggest that DMSO and water extracts of Turkish propolis may have antimetastatic activity in PC-3 cells due to down-regulation of expressions mRNA of VGSC $\alpha$-isoforms.
\end{abstract}

Keywords: Propolis, Voltage-gated sodium channel (VGSC), PC-3 Human prostate cancer cells

Tropical Journal of Pharmaceutical Research is indexed by Science Citation Index (SciSearch), Scopus, International Pharmaceutical Abstract, Chemical Abstracts, Embase, Index Copernicus, EBSCO, African Index Medicus, JournalSeek, Journal Citation Reports/Science Edition, Directory of Open Access Journals (DOAJ), African Journal Online, Bioline International, Open-J-Gate and Pharmacy Abstracts

\section{INTRODUCTION}

Propolis is a bee product which has been used in folk medicine since ancient times [1]. It is composed of $50 \%$ resin, $30 \%$ wax, $10 \%$ essential and aromatic oils, $5 \%$ pollen and $5 \%$ various other substances, including organic debris. Propolis contains considerable amounts of flavonoids, polyphenolic substances such as quercetin, caffeic acid and caffeic acid phenethyl ester (CAPE), pinocembrin, galangin, p-coumaric acid. These componenets are potent antioxidants, but there is a problem of standardization [1,2]. Propolis has anti-bacterial, anti-viral, anti-fungal, immune-modulatory, antiinflammatory, anesthetic, cytotoxic, antiproliferative and anti-mutagenic effects [1].

Prostate cancer is one of the most commonly diagnosed cancers in men and the first leading cause of cancer-related deaths in the United States of America and the European Union [3-5]. MR/IR (mortality rate to incidence rate ratio) of prostate cancer is as high as $40 \%$ in Asia compared to $18 \%$ in Europe, $10 \%$ in Northern America and $25 \%$ worldwide [6]. The etiology of prostate cancer is multifactorial, and a number of dietary and lifestyle factors have been implicated 
in the development and progression of the disease [5]. In addition, prostate cancer cells usually metastasize mainly to bones, lymph nodes and lungs body [3].

VGSCs are integral membrane proteins which usually mediate fast transport of $\mathrm{Na}^{+}$in and out of cells depending on electrochemical gradient. They are functionally up- regulated in metastatic prostate cancer cells like breast cancer, smallcell lung cancer, non-small-cell lung cancer, mesothelioma, melanoma and cervical cancer cells [7]. VGSCs contain a subunit and one or more $\beta$ subunits. The VGSC $\alpha$ subunit gene family consists of 10 members (Nav 1.1-1.9 and Navx) and $\beta$ subunits consist of 4 members ( $\beta 1$ $\beta 4)$ and one splice variant of $\beta 1 A$, which have distinct tissue specificities and developmental expression profiles. VGSC Nava 1.5 mRNA was detected in most human tissues assayed and showed the strongest expression in the heart, and high level in adult and fetal brain, the testes and the prostate. VGSC Nav 1.7 mRNA was also present in most tissues assayed, and the highest expression was found in the testes, adult and fetal whole brain, and placenta [8].

According to the CELEX hypothesis, phytochemicals like resveratrol, curcumin, capsaicin, genistein and ginseng, omega-3 polyunsaturated fatty acids and minerals have anti-cancer effects through down-regulating of VGSC expression, and partly up-regulated VGKC (Voltage-Gated Potassium Channel Protein) expression [9].

In this study, we investigated the effects of propolis extracts on mRNA expression of VGSC Nav 1.5 and Nav 1.7 a-isoforms in PC-3 cells.

\section{EXPERIMENTAL}

\section{Chemicals}

DMSO, was supplied from Merck (Berlin, Germany), Dulbecco's Modification of Eagles's Medium (DMEM)/Ham's F12 with L-Glutamine, 3-(4,5-Dimethylthiazol-2-yl)-2,5-

diphenyltetrazolium bromide (MTT), penicillin and streptomycin were products ofSigma (St. Louis, MO, USA). RPMI 1640, L-Glutamine and Fetal Bovine Serum (FBS) were obtained from GIBCO (Paisley, England). PBS-Dulbecco, Trypsin/EDTA solution and Trypan Blue were supplied by Biochrom AG (Berlin, Germany). Ethanol was obtained from Carlo Erba (Milano, Italy), $100 \mathrm{mM}$ dNTPs from Fermantas Life Sciences (Ontario, Canada), while reverse transcriptase (AMV) was got from Roche Diagnostics (GmbH, Mannhein, Germany).

\section{Propolis}

Propolis samples, produced by honey-bee (Apis mellifera L.) in various regions of Turkey, were provided by Fanus Food Company (Trabzon, Turkey) and mixed to obtain Turkish propolis sample. Turkey is rich in Picea orientalis, Fagus orientalis, Castanea sativa, Rhodendron ponticum, Rhododendron luteum, Rubus caucasicus [10].

Analysis of the phenolic compounds (flavonoids) of Turkish propolis was previously carried out in our laboratory. According to HPLC analysis, the main flavonoids of DMSO extracts of propolis were found to be galangin, naringenin, chrysin, kaempferol, quercetin and cinnamic acid derivatives, while caffeic and caffeoyl quinic acids were present in the water extracts [11].

\section{Preparation of DMSO and water extracts of Turkish propolis}

Each natural propolis samples were ground (Retsch, ZM 200) then frozen at $-80{ }^{\circ} \mathrm{C}$. The ground propolis samples were mixed and bottled in $5 \mathrm{~g}$-portions. The portions were dissolved in 20 $\mathrm{mL}$ of DMSO (100\% w/v) or deionized water by continuous shaking in an incubator (Shelleb/Sheldon Mod: 514, USA) at $150 \mathrm{rpm}$ and $60{ }^{\circ} \mathrm{C}$ for $24 \mathrm{~h}$. Extracts of $250 \mathrm{mg} / \mathrm{mL}$ concentrations were obtained by centrifuging at $4000 \mathrm{rpm}$ for $10 \mathrm{~min}$. Collected supernatants were mixed and stored at $4{ }^{\circ} \mathrm{C}$ in the dark. Working solutions at concentration of $20 \mu \mathrm{g}$ aqueous extract/mL and $\mu \mathrm{g}$ DMSO extract $/ \mathrm{mL}$ were prepared by diluting stock WEP and DMSO extracts with deionized water and DMSO respectively.

\section{Cell culture}

PC-3 human prostate carcinoma cells were obtained from Hematology Department of Gulhane Military Medical Academy in Ankara, Turkey. The cells were cultured in RPMI 1640 medium containing L-Glutamine (GIBCO), $10 \%$ FBS (Sigma) and $1 \%$ penicillin/streptomycin (Sigma) solution at $37{ }^{\circ} \mathrm{C}$ in a humidified atmosphere containing $5 \% \mathrm{CO}_{2}$. Subcultures were carried out every 3-4 days using $0.25 \%$ trypsin-0.02\% EDTA solution.

\section{Extraction of total RNA}

PC-3 cells at a density of $1.5 \times 10^{5}$ cells were placed in T-25 flasks, cultured in duplicate and 
incubated for $24 \mathrm{~h}$. Then $0.5 \mathrm{~mL}$ of $20 \mu \mathrm{g} / \mathrm{mL}$ WEP, $20 \mu \mathrm{g} / \mathrm{ml}$ DMSO extract of Turkish propolis and $1 \mathrm{ml}$ of FBS were added to $8.5 \mathrm{~mL}$ of RPMI1640 and the cancer cells were incubated for 24 $\mathrm{h}$ at $37{ }^{\circ} \mathrm{C}$ and $5 \% \mathrm{CO}_{2}$ after adding the new medium mixture. PC-3 cells which were not treated with any extract were used as a control.

For total RNA extraction from PC-3 cells (Treated and not treated with propolis extracts), QIAGEN ( $\mathrm{GmbH}$, Hilden, Germany) OIAamp RNA Blood Mini Kit (Cat.No. 52304) was used. The protocol recommended by the kit manufacturer for RNA extraction from cells samples was precisely followed.

\section{Synthesis of primers and cDNA}

All primers were designed by Ocimum Biosolution B.V. (Holland). For Nav 1.5 (hH1): primers forward 5'-CAT CCT CAC CAA CTG CGT GT-3' (570-589) and reverse (hH2) 5'-CAC TGA GGT AAA GGT CCA GG-3' (10559-1078). For Nav1.7 (HNE1) primers forward 5'-TAT GAC CAT GAA TAA CCC GC-3' (474-493) and reverse (HNE3) 5'-TCA GGT TTC CCA TGA ACA GC-3' (843-862). For $\beta$-Actin (Hb-actinF) primers forward 5'-CAC TGA GGT AAA GGT CCA GG-3' and reverse (Hb-actinR) 5'-TGT CAA AGT TGA TCT TCA CG-3'.

cDNA was synthesized from $5 \mu \mathrm{L}$ of total RNA in a final volume of $20 \mu \mathrm{L}$ reaction using the AMV(Avian Myeloblastosis Virus) Reverse Transcriptase (Roche Diagnostics, $\mathrm{GmbH}$, Mannhein, Germany) with Nav 1.5, Nav 1.7 and $\beta$-Actin primers at $2.5 \mu \mathrm{L}$ from $10 \mathrm{pmol}$ following the manufacturer's protocol.

\section{Real-time PCR}

For real-time (RT)-PCR assay, Roche Applied Science LightCycler® DNA Master SYBR Green I kit (Cat. No: 12015099 001) was used. cDNA $(5 \mu \mathrm{L})$ was amplified by RT-PCR with 10x Roche Applied Science LightCyclerß DNA Master SYBR Green I and $10 \mathrm{pmol} / \mu \mathrm{L}$ target primers. $\beta$ Actin was used as the housekeeping gene. Each sample was analyzed with negative control in duplicate using LightCycler 2.0 System (Roche). The reaction conditions were as follows: 1 cycle $95{ }^{\circ} \mathrm{C} / 30 \mathrm{~s}, 45$ cycle of $50{ }^{\circ} \mathrm{C} / 15 \mathrm{~s}, 72{ }^{\circ} \mathrm{C} / 20 \mathrm{~s}$, and the melting curve: $95{ }^{\circ} \mathrm{C} / 30 \mathrm{~s}, 60{ }^{\circ} \mathrm{C} / 15 \mathrm{~s}$ and $40{ }^{\circ} \mathrm{C} / 30 \mathrm{~s}$. PCR amplification was related to a Standard curve. The smallest dilution of cDNA Standard was given the relative value 100 and, following the same reason of dilution, other three points were 10, 1 and 0.1 . The results were expressed as percentage of differences relative to normal controls (relative expression) using (Software 4.05).

\section{Data analysis}

All data were expressed as arithmetic mean \pm standard deviation (SD).

\section{RESULTS}

\section{Expression of Nav 1.5 and Nav $1.7 \alpha$ isoforms of VGSC}

As shown in Table 1, both extracts decreased expressions of VGSC Nav 1.5 and Nav 1.7 to different extents. Lower expressions of VGSC Nav 1.5 and Nav 1.7 were obtained in PC-3 cells incubated with $20 \mu \mathrm{g} / \mathrm{mL}$ DMSO extract of Turkish propolis $(61.43 \pm 4.92$ and $58.17 \pm 2.88$ $\%$, respectively) but higher expressions of VGSC Nav 1.5 and Nav 1.7 were obtained in PC-3 cells incubated with $20 \mu \mathrm{g} / \mathrm{mL}$ aqueous extract of Turkish propolis (83.54 \pm 15.96 and $80.40 \pm$ $13.87 \%$, respectively).

\section{DISCUSSION}

The poplar origin of Turkish propolis has been well documented [12,13]. Propolis samples collected in various regions of Turkey have been investigated for antibacterial, antifungal, antioxidant and anti-carcinogenic activities $[13,15]$.

Cinnamic acid and cinnamic acid derivatives, pinocembrin, pinobanksin, chrysin, galangin, vanillin, p-cumaric acid, ferulic acid, caffeic acid, naringenin, CAPE have been detected in Turkish propolis $[11,13,14]$. In addition, it has been reported that propolis collected from different countries contain phenolic compounds like genistein [16], catechin and resveratrol [17].

Table 1: VGSC Nav 1.5 and Nav 1.7 expression levels in PC-3 cells incubated with $20 \mu \mathrm{g} / \mathrm{mL}$ DMSO and WEP of Turkish propolis

\begin{tabular}{lcc}
\hline Variable & Water extract (\%) & DMSO (\%) \\
\hline Nav1.5 expression & $83.54 \pm 15.96$ & $61.43 \pm 4.92$ \\
Nav1.7 expression & $80.40 \pm 13.87$ & $58.17 \pm 2.88$ \\
\hline \multicolumn{2}{l}{ Values are mean \pm SD, $n=3$. Control } & PC-3 cells not incubated with any extracts were taken as $100 \%$ expression \\
of VGSC Nav 1.5 and Nav 1.7 $\alpha$ isoform &
\end{tabular}


In previous study, it was reported that aqueous and DMSO extracts of propolis had antioxidant properties to different extent [18]. In MTT assay results, aqueous and DMSO extracts showed cytotoxic effects on PC-3 cells depending on the concentration [18]. The results of MTT assay for propolis in PC-3 cells are in agreement with those obtained for Turkish propolis by Turan et al [15] and Cuban propolis by Carballo et al [19]. Based on results from cytotoxic assays, 20 $\mu \mathrm{g} / \mathrm{mL}$ propolis was chosen for Real-Time PCR assay of VGSC Nav 1.5 and 1.7 -isoforms.

In this study, expression levels of both VGSC Nav 1.5 and $1.7 \alpha$ - isoforms were reduced by DMSO and WEP in PC-3 cells when compared with control PC-3 cells which were not incubated with extracts. The highest reduction in expression of VGSC Nav 1.5 and $1.7 \alpha$ isoforms was obtained in PC-3 cells incubated with 20 $\mu \mathrm{g} / \mathrm{mL}$ DMSO extract of propolis. This result may be related to synergistic effect of some antioxidant compounds in propolis, especially in the DMSO extract. This study is the first in literature on investigation of expression of VGSCs isoforms in PC-3 cells incubated with extracts of propolis.

Experimental data on VGSC Nav 1.5 and Nav 1.7 a-isoform expressions are in consonance with CELEX hypothesis. The effects of these extracts may be related to flavonoids, polyphenolics, minerals and fatty acid content of Turkish propolis. Previous studies have shown that propolis contains resveratrol, genistein as well as polyphenolic compounds, $\mathrm{Zn}^{+}$other minerals and fatty acids. Fraser et al [20] reported that resveratrol dose-dependently inhibited the activity of VGSC and significantly suppressed lateral motility, transverse motility and invasion in strongly metastatic MAT Ly-Lu prostate cancer cells [20].

Since propolis is natural and non-toxic to humans at low concentrations, researchers may find this natural product a suitable candidate antimetastatic substance a viable substitute for toxic tetrodotoxin in blocking VGSC activity in cancer cells.

\section{CONCLUSION}

The findings show that both aqueous and DMSO extracts of Turkish propolis decrease the expression of VGSC Nav 1.5 and 1.7 -isoforms in PC-3 cells. Further studies to investigate the effects of propolis extracts with different concentrations on expression of all isoforms of VGSC, function of VGSC and protein level in PC3 and the other cancer cells are required to ascertain contribution of antitumoral and antimetastatic activities of propolis.

\section{DECLARATIONS}

\section{Acknowledgement}

This research was supported by Foundation of Karadeniz Technical University (Project Number: 2007.114.0012), Trabzon, Turkey.

\section{Conflict of Interest}

No conflict of interest associated with this work.

\section{Contribution of Authors}

The authors declare that this work was done by the authors named in this article and all liabilities pertaining to claims relating to the content of this article will be borne by them.

\section{REFERENCES}

1. Burdock GA. Review of the Biological Properties and Toxicity of Bee Propolis (Propolis). Food Chem Toxicol 1998; 36: 347-363.

2. Socha R, Galkowska D, Bugaj M, Juszczak L. Phenolic composition and antioxidant activity of propolis from various regions of Poland. Nat Prod Res 2015; 29: 416422.

3. Heidenreich A, Bellmunt J, Bolla M, Joniau S, Mason M, Matveey $V$, Motter $N$, Schmid $H D$, Van der Kwast $T$, Wiegel $T$ et al. EAU Guidelines on Prostate Cancer. Part 1: Screening, Diagnosis, and Treatment of Clinically Localised Disease. Eur Urol 2011; 59: 61-71.

4. Ferlay J, Foucher ES, Tieulent JL, Rosso S, Coebergh JWW, Comber H, Forman D, Bray F. Cancer incidence and mortality patterns in Europe: Estimates for 40 countries in 2012. Eur J Cancer 2013; 49: 1374-1403.

5. Siegel RL, Miller KD, Jemal A. Cancer Statistics. Ca Cancer J Clin 2015; 65:5-29.

6. Chen R, Ren S, Chinese Prostate Cancer Consortium, Yiu MK, Fai NC, Cheng WS, Ian LH, Naito S, Matsuda $T$, Kehinde E, Kural A, Chiu JY, Umbas R, Wei Q, Shi X, Zhou L, Huang J, Huang $Y$, Xie L, Ma L, Yin C, Xu D, Xu K, Ye Z, Liu C, Ye D, Gao X, Fu Q, Hou J, Yuan J, He $D$, Pan T, Ding Q, Jin F, Shi B, Wang G, Liu X, Wang D, Shen Z, Kong X, Xu W, Deng Y, Xia H, Cohen AN, Gao $X, X u$ C, Sun Y. Asian Focus Prostate Cancer in Asia: $A$ Collaborative Report. Asian Journal of Urology 2014; 1 : 15-29.

7. Onkal $R$, Djamgoz MBA. Review Molecular pharmacology of voltage-gated sodium channel expression in metastatic disease: Clinical potential of neonatal Nav 1.5 in breast cancer. Eur J Pharmacol 2009; 625: 206-219. 
8. Candenas $L$, Seda $M$, Noheda $P$, Buschamann $H$, Cintado CG, Martin JD, Pinto FM. Molecular diversity of voltage-gated sodium channel $\alpha$ and $\beta$ subunit mRNAs in human tissues. Eur J Pharmacol 2006; 541: 9-16.

9. Djamgoz MBA, Isbilen B. Dietary Compouds As Anticancer Agents: A Preliminary Evaluation of Ion Channels And Membrane Excitability As Possible Target Mechanisms. Turk J Biochem 2006; 31: 57-68.

10. Davis PH. Flora of Turkey and the East Aegean Islands, Edinburgh University Press, Edinburgh, 1965-1985; Vols. 1-9.

11. Cakiroglu TN. Investigation of Solubility of Turkish Propolis in Different Solvents. Master Thesis, Karadeniz Technical University, Institute of Health Sciences, Trabzon, Turkey 2010.

12. Velikova M, Bankova V, Sorkun K, Popov S, Kujumgiev A. Chemical biological activity of propolis from Turkish and Bulgarian origin. Mellifera 2001; 1: 57-59.

13. Popova M, Silici S, Kaftangolu O, Bankova V. Antibacterial activity of Turkish propolis and its qualitative and quantitative chemical composition. Phytomedicine 2005; 12: 221-228.

14. Uzel A, Sorkun K, Oncag O, Cogulu D, Gencay O, Salih $B$. Chemical compositions and antimicrobial activities of four different Anatolian propolis samples. Microbiol Res 2005; 160: 189-195.
15. Turan I, Demir S, Misir S, Kilinc $K$, Mentese $A$, Aliyazicioglu Y, Deger O. Cytotoxic Effect of Turkish Propolis on Liver, Colon, Breast, Cervix and Prostate Cancer Cell Lines. Trop J Pharm Res 2015; 14(5): 777782.

16. Fu SH, Yang MH, Wen HM, Chern JC. Analysis of flavonoids in propolis by capillary electrophoresis. J Food Drug Anal 2005; 13(1): 43-50.

17. Volpi, N. Separation of flavonoids and phenolic acids from propolis by capillary zone electrophoresis. Electrophoresis 2004; 25: 1872-1878.

18. Barlak Y, Değer O, Çolak M, Karataylı SC, Bozdayı AM, Yücesan F. Effect of Turkish propolis extracts on proteome of prostate cancer cell line. Proteome Sci 2011; 9(74): 1-11.

19. Carballo DD, Malak S, Bardenheuer W, Freistuehler M, Reusch $\mathrm{PH}$. The contribution of plukenetione $A$ to the anti-tumoral activity of Cuban propolis. Bioorg Med Chem 2008; 16: 9635-9643.

20. Fraser SP, Peters A, Fleming JS, Mukhey D, Djamgoz $M B$. Resveratrol: Inhibitory effects on metastatic cell behaviors and voltage-gated $\mathrm{Na}^{+}$channel activity in rat prostate cancer in vitro. Nutr Cancer 2014; 66(6): 10471058. 